\title{
Effect of vaccination in lowering the prevalence of bovine brucellosis in the state of Mato Grosso, Brazil
}

\section{Efeito da vacinação no rebaixamento da prevalência da brucelose bovina no estado de Mato Grosso, Brasil}

\author{
Janice Elena Ioris Barddal ${ }^{1 *}$; Jociane Cristina Quixabeira-Santos ${ }^{2}$; \\ Isabela Ferreira Lopes ${ }^{2}$; José Soares Ferreira Neto ${ }^{3}$; Fernando Ferreira ${ }^{3}$; \\ Marcos Amaku ${ }^{3}$; Ricardo Augusto Dias ${ }^{3}$; Evelise Oliveira Telles ${ }^{3}$; \\ José Henrique Hildebrand Grisi-Filho ${ }^{3}$; Marcos Bryan Heinemann ${ }^{3}$; \\ Vitor Salvador Picão Gonçalves ${ }^{4}$; Daniel Moura Aguiar ${ }^{5}$
}

\begin{abstract}
The study was conducted to verify the efficacy of the bovine brucellosis vaccination program implemented by the state of Mato Grosso, using prevalence as an indicator. The state was divided into four regions: Pantanal, Milk, Fattening, and Breeding. For each region, a predetermined number of properties were selected and blood samples were taken from randomly chosen female animals, aged 24 months or greater. Sera from the animals were initially screened with a buffered acidified plate antigen, and confirmed using complement fixation. In each property, a questionnaire was used in order to identify the risk factors associated with the disease. In the state, the prevalence rate of infected herds was $24.0 \%$ $[21.3 ; 26.8]$ and the prevalence rate of infected animals was $5.1 \%[3.5 ; 7.2]$. The prevalence rates of infected herds and animals in each region were as follows: $21.2 \%$ and $6.4 \%$ in the Pantanal region, $17.2 \%$ and $3.7 \%$ in the Milk region, $34.0 \%$ and $7.2 \%$ in the Fattening region, and $24.3 \%$ and $4.4 \%$ in the Breeding region. Bovine brucellosis in the state is associated with the introduction of breeding, herd size, pasture sharing, and farms used for mixed and beef purposes. Therefore, in order to improve control of bovine brucellosis, it is proposed that the state of Mato Grosso intensify its prophylactic program, primarily its vaccination strategy. There has been a reduction in the prevalence of infected herds since 2002; however, there remains a high prevalence of infected herds and animals throughout the state. Additionally, the use of non-inducing antibodies vaccine should be encouraged, especially in the Pantanal region where the management of the animals is complicated by the flood and ebb cycle. The state should make greater efforts to educate producers on how to assess the breeding animals for brucellosis before introducing them into their properties as well as avoid shared grazing among herds of unknown health conditions.
\end{abstract}

Key words: Bovine brucellosis. Vaccination. Prevalence. Risk factors. Mato Grosso. Brazil.

\footnotetext{
${ }^{1}$ Auditora Fiscal Federal Agropecuário, Ministério da Agricultura, Pecuária e Abastecimento, MAPA, Cuiabá, MT, Brasil. E-mail: janice.barddal@agricultura.gov.br

2 Médicos Veterinários, Instituto de Defesa Agropecuária do Estado de Mato Grosso, INDEA, Cuiabá, MT, Brasil. E-mail: isabelavet@hotmail.com; jocianequixabeira@yahoo.com.br

${ }^{3}$ Profs., Faculdade de Medicina Veterinária e Zootecnia, Universidade de São Paulo, USP, São Paulo, SP, Brasil. E-mail: grisi@ vps.fmvz.usp.br; fernando@vps.fmvz.usp.br; amaku@vps.fmvz.usp.br; dias@vps.fmvz.usp.br; evelise@vps.fmvz.usp.br; marcosbryan@usp.br; jsoares@vps.fmvz.usp.br

${ }^{4}$ Prof., Faculdade de Agronomia e Medicina Veterinária, Universidade de Brasília, UNB, Brasília, DF, Brasil. E-mail: vitorspg@ unb.br

5 Prof., Faculdade de Medicina Veterinária, Universidade Federal do Mato Grosso, UFMT, Cuiabá, MT, Brasil. E-mail: danmoura@ ufmt.br

* Author for correspondence
} 


\section{Resumo}

O estudo foi realizado para se verificar a eficácia do programa de vacinação contra brucelose bovina implementado pelo estado de Mato Grosso, utilizando-se a prevalência como indicador. O Estado foi dividido em quatro regiões: Pantanal, Leite, Engorda e Cria. Para cada região, um número preestabelecido de propriedades foi selecionado e em cada uma delas foram colhidas amostras de sangue de fêmeas com idade igual ou superior a 24 meses, aleatoriamente escolhidas. Os soros dos animais foram submetidos a um protocolo de testes em série, com triagem pelo teste com Antígeno Acidificado Tamponado e confirmação pela Fixação do Complemento. Em cada propriedade foi aplicado um questionário para individualizar os fatores de riscos associados à doença. No estado, a prevalência de focos foi $24,0 \%$ $[21,3 ; 26,8]$ e a de animais $5,1 \%[3,5 ; 7,2]$. As prevalências de focos e de animais nas regiões foram $21,2 \%$ e $6,4 \%$ no Pantanal, $17,2 \%$ e 3,7\% na região Leite, $34,0 \%$ e $7,2 \%$ na região de Engorda e $24,3 \%$ e 4,4\% na região de Cria. A brucelose bovina no estado está associada à introdução de reprodutores, ao tamanho do rebanho, ao compartilhamento de pastagem e ao tipo de exploração corte e mista. Propõe-se assim que o estado de Mato Grosso intensifique seu programa profilático principalmente a estratégia de vacinação, buscando maior eficácia do controle da brucelose bovina. Houve redução na prevalência de focos desde 2002, entretanto, ainda são altas as prevalências de focos e de animais em todo o estado. Adicionalmente a utilização da vacina não indutora de anticorpos, especialmente no Pantanal deve ser estimulada, onde o manejo dos animais é dificultado pelo ciclo de cheia e vazante. Além disso, o estado deve realizar maiores esforços no sentido de conscientizar os produtores para que avaliem os animais de reprodução para brucelose antes de introduzi-los nas propriedades e evitem o compartilhamento de pastagens entre rebanhos de condição sanitária desconhecida.

Palavras-chave: Brucelose bovina. Vacinação. Prevalência. Fatores de risco. Mato Grosso. Brasil.

\section{Introduction}

Mato Grosso is home to 3 million inhabitants and is a state that exports meat with an effective beef production of approximately 28 million heads. In 2014, meat export generated R $\$ 1.2$ billion in revenue for the state, representing $19 \%$ of all export of Brazilian beef (ACRIMAT, 2015). The Mato Grosso Institute of Agricultural Economics and the Federation of Agriculture and Livestock of Mato Grosso reported that agribusiness is the largest generator of jobs in the state, accounting for $27 \%$ of employees hired in 2012.

Cattle diseases, especially those that affect reproduction, represent a major obstacle to the development of the livestock industry. In Brazil, brucellosis is caused by the bacterium Brucella abortus and the main disease that affects the reproduction of cattle. Every 1\% variation in the prevalence of bovine brucellosis corresponds to an estimated $\mathrm{R} \$ 155$ million damage that is caused by bovine brucellosis in Brazil (SANTOS et al., 2013).

In cattle, the main signs of the disease are miscarriage in the late trimester, placenta retention, stillbirth, and birth of weak calves (PAULIN; FERREIRA NETO, 2003, 2002). This disease generates economic losses due to the increase in the calving interval, a drop in the birth of calves, decreased production of meat and milk, and an increase in animal replacement rate (FARIA, 1984). The disease hinders the marketing of animals and animal products and compromises the country's competitiveness in the international market (LAGE, 2006). This also involves losses related to the cost of human treatment and the absence from work during convalescence (PAULIN; FERREIRA NETO, 2003). Humans can be exposed by contact with infected animals or consumption of unpasteurized milk. Cowboys, handlers, veterinarians, milkers, and slaughterers are in high-risk occupations where one can become infected through contact with the fetus, attachments, or fetal fluids of the infected female and accidents with live vaccines (PAULIN; FERREIRA NETO, 2003).

In 2001, the Ministry of Agriculture, Livestock and Supply (MAPA), with awareness for the need to 
properly control the disease, developed and launched the National Program for Control and Eradication of Brucellosis and Tuberculosis (PNCEBT) (LAGE, 2006). The Collaborating Center for Animal Health of the Faculty of Veterinary Medicine and Animal Science at the University of São Paulo was instructed to standardize methodology and perform cross-sectional studies in all Federal Units in order to choose the most appropriate strategies and perform management processes (POESTER et al., 2009). Initial studies have been conducted in 18 Federative Units, representing $85 \%$ of the actual Brazilian cattle population. The lowest prevalence of infected herds was detected in the state of Santa Catarina $(0.32 \%)$ and the highest in Mato Grosso do Sul (41.5\%). Mato Grosso (41.2\%) was among the group of states with very high prevalence rates of infected herds (SIKUSAWA et al., 2009; ALVES et al., 2009; AZEVEDO et al., 2009; CHATE et al., 2009; DIAS et al., 2009a, 2009b; GONÇALVES et al., 2009a, 2009b; KLEIN-GUNNEWIEK et al., 2009; MARVULO et al., 2009; OGATA et al., 2009; ROCHA et al., 2009; SILVA et al., 2009; VILLAR et al., 2009; NEGREIROS et al., 2009; BORBA et al., 2013; ALMEIDA et al., 2016; CLEMENTINO et al., 2016). After approximately ten years, the states of São Paulo, Minas Gerais, Espirito Santo, Rondônia, Mato Grosso do Sul, and Rio Grande do Sul conducted the second brucellosis prevalence study to verify the effectiveness of their immunization programs. However, the prevalence of infected herds only decreased in Mato Grosso do Sul, Minas Gerais and Rondônia (DIAS et al., 2016; ANZAI et al., 2016; INLAMEA et al., 2016; LEAL FILHO et al., 2016; OLIVEIRA et al., 2016; SILVA et al., 2016). The state of Santa Catarina, which had the lowest prevalence of infected herds and animals, prohibited vaccination and began the implementation of eradication strategies. They also conducted a second study, which did not indicate changes in prevalence (BAUMGARTEN et al., 2016).

Due to the high prevalence previously observed in Mato Grosso, it was recommended that the state form an effective vaccination program with B19 and target an annual vaccination coverage of $80 \%$ of calves from 3 to 8 months of age (AMAKU et al., 2009). In addition, in order to increase vaccination coverage, the state was encouraged to vaccinate adults with no inducing antibodies vaccine from 2007. Their implementation was regulated by SDA Normative Instruction Number 33 on August 24, 2007.

Thus, the state of Mato Grosso made vaccination with B19 mandatory in 2003 and established the mandatory vaccination against brucellosis for issuing the animal transport formulary in 2005. This significantly contributed to the increase in vaccination rates, which increased from $54 \%$ in 2005 to $82 \%$ in 2006 . They remained above $80 \%$ until 2014, with the exception of 2011 due to a shortage of inputs (Figure 1). Vaccination rates in the Pantanal, Fattening, Milk and Breeding regions proved to be homogeneous. In 2013, the state made vaccination with the non-antibody inducing vaccine mandatory in the default properties.

In 2013, in the Pantanal region, where the handling of the animals is complicated by the flood and ebb cycle, the state allowed the use of non-antibody inducing vaccines to replace B19 (INDEA, 2013), but the accession of producers has been low due to the availability of the vaccine and its cost. Therefore, this study aimed to evaluate the effectiveness, using prevalence as an indicator, of the vaccination program implemented in the state. This study also aimed to individualize the risk factors associated with bovine brucellosis. 
Figure 1. Rate of annual vaccination of calves with B19 in the state of Mato Grosso.

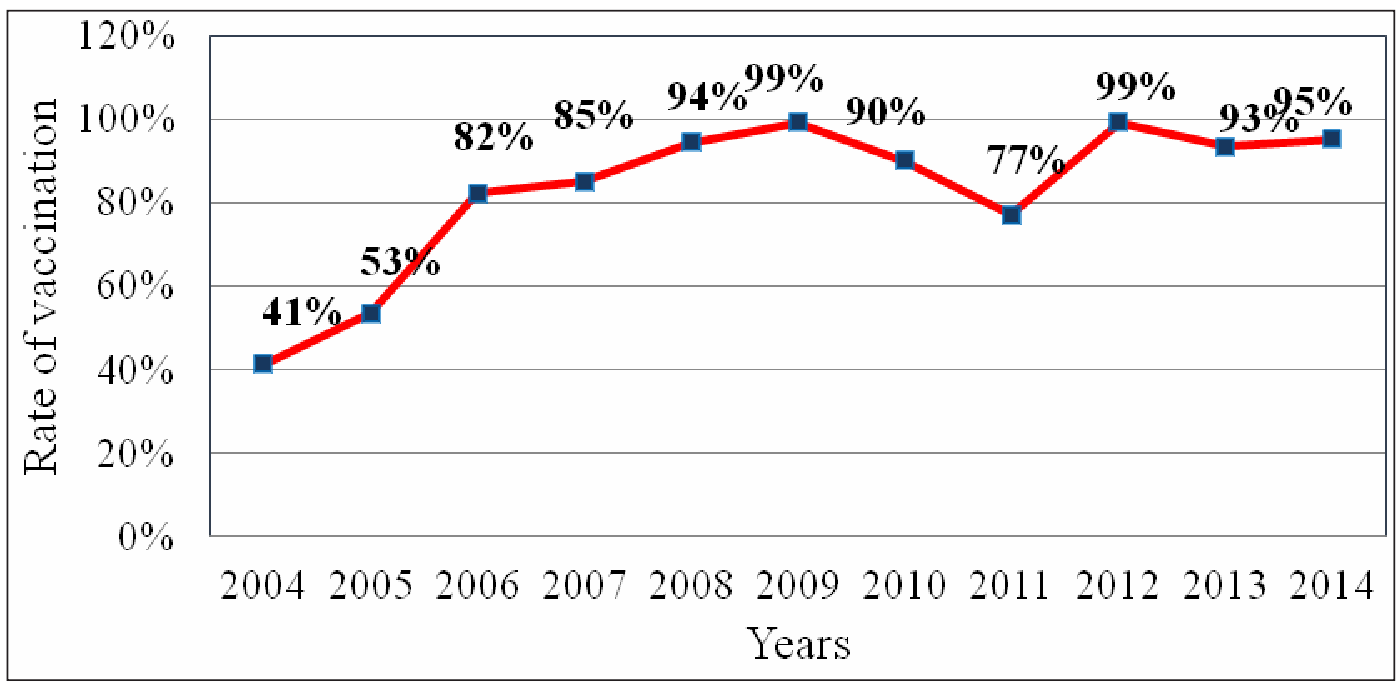

\section{Methods and Materials}

The study was designed by staff personnel from MAPA, the Collaborating Center for Animal Health (Faculty of Veterinary Medicine and Animal Science at the University of São Paulo [FMVZ-USP]), the Federal University of Mato Grosso (UFMT) and the State Agricultural Defense Institute of Mato Grosso (INDEA). INDEA veterinarins carried out the fieldwork from September to December of 2014.

Initially, the state was divided into regions, taking into consideration the different production systems, management practices, types of operation, average herd sizes, animal commercialization system, and the operational capacity of the animal health protection service. Within each of these regions, a predetermined number of properties with reproductive activity (primary sampling units) were randomly chosen. This process was based on property records maintained by INDEA. Within each selected property, a predetermined number of cows aged over 24 months were drawn at random (secondary sampling units).

In rural properties with more than one flock, the herd with greater economic importance was chosen as the target of the study and the animals were subjected to the same type of management (i.e., under the same risk factors). The choice of the primary sampling unit was random and based on the registration of farms with reproductive activity of cattle. Properties that were drawn but could not be visited for various reasons were replaced by another nearby property that had the same production characteristics (THRUSFIELD, 2007). The parameters designated for the calculation were as follows: a confidence level of 0.95 , estimated prevalence of 0.20 , and 0.05 error.

For secondary units, a minimum number of animals to be examined within each property was estimated in order to determine if it would be classified as a herd that was infected or not infected by brucellosis. We used the concepts of sensitivity and specificity aggregates (DOHOO et al., 2003). For purposes of calculation, values of $95 \%$ and $99.5 \%$ were adopted for sensitivity and specificity of the test protocols, respectively, (FLETCHER et al., 1998) and 20\% for the estimated intra-herd prevalence. This was processed using the Herdacc program version 3 and the sample size was chosen to enable a sensitivity and specificity greater than or equal to $90 \%$ for the herd. Thus, in properties with up to 99 female bovine older than 24 months, 10 animals were sampled; 15 animals were sampled in properties with 100 or more female animals older than 24 months. The choice of female animals within the properties was casual systematic. Cows 
in the peripartum period or abortion, i.e., about 15 days before and after delivery, were excluded from the selection.

The blood $(10 \mathrm{ml})$ was collected by puncturing the jugular vein with a sterile disposable needle in a previously identified vacuum tube. The sera stored in plastic wells were kept at $-20{ }^{\circ} \mathrm{C}$ until testing. The serodiagnosis protocol consisted of screening with the buffered acidified antigen test and positivity was confirmed by a subsequent complement fixation test. These tests were conducted by the Laboratory of Animal Health Support INDEA (LASA-MT) and National Agricultural Laboratory (LANAGROMG). The property was considered positive when at least one positive animal was detected.

The sample design allowed us to determine the prevalence of infected herds and adult female animals ( $\geq 24$ months) seropositive for brucellosis in the state and in the regions. Estimates of the prevalence and confidence intervals were performed as recommended by Dean et al. (1994). Estimates of the prevalence of infected herds and animals in the state and prevalence of animals in the regions were made in a balanced manner based on the method of Dohoo et al. (2003).

The weight of each property in calculating the prevalence of infected herds in the state was given by the following equation:

$$
P_{1}=\frac{\text { properties in the region }}{\text { properties sampled in the region }}
$$

The weight of each animal in the calculation of the prevalence of animals in the state was given by the following equation:

$$
P_{2}=\frac{\text { female bovine } \geq 24 \text { months in the property }}{\text { Female animals } \geq 24 \text { months sampled in the }} \times-
$$

Female bovine $\geq 24$ months in the region

Female animals $\geq 24$ months sampled in the region
In the above expression, the first term refers to the weight of each animal in the calculation of animal prevalence within regions. Estimates of the prevalence and confidence intervals of $95 \%$ were made through EpiInfo 6.0 and SPSS software, version 9.0.

In each sampled property, during the blood samples drawn, an epidemiological questionnaire designed to obtain information on the type of farming and management practices employed was conducted.

The following variables were analyzed: type of operating system (beef, dairy and mixed), type of breeding (confined, semi-confined, extensive), use of artificial insemination, predominant breeds, number of animals, the presence of other domestic and wild species, occurrence of abortion in the last two years, the destination of placenta and aborted fetuses, purchase of animals, vaccination against bovine brucellosis, pastures sharing with other properties, occurrence of flooding in the grasslands, existence of picket lambing, and veterinary care.

The variables were arranged in ascending scale of risk. When necessary, they were re-categorized. The lower risk category was used as a basis for comparison to the other categories. Quantitative variables were categorized into percentiles. An exploratory analysis (univariate) for selection of those with $\mathrm{p}<0.20$ for the $\chi^{2}$ test (chi-square) or Fisher's exact test and subsequent logistic regression was conducted, as recommended by Hosmer and Lameshaw (1989). The calculations were performed with SPSS. All information generated by field and laboratory work was included in a specific database used in epidemiological studies.

\section{Results}

The state was divided into four regions (Figure 2). Table 1 provides a summary of census and sample data. Table 2 shows the prevalence of infected herds and animals in the region and the 
state. The prevalence of infected herds by type of farming in the regions is shown in Table 3. Table 4 shows the comparison of this study with that conducted in 2002 by Negreiros et al. (2009). Table
5 shows the results of the univariate analysis and Table 6 shows the final logistic regression model for risk factors associated with herds infected with bovine brucellosis in Mato Grosso.

Figure 2. Map of the State of Mato Grosso divided into regions.

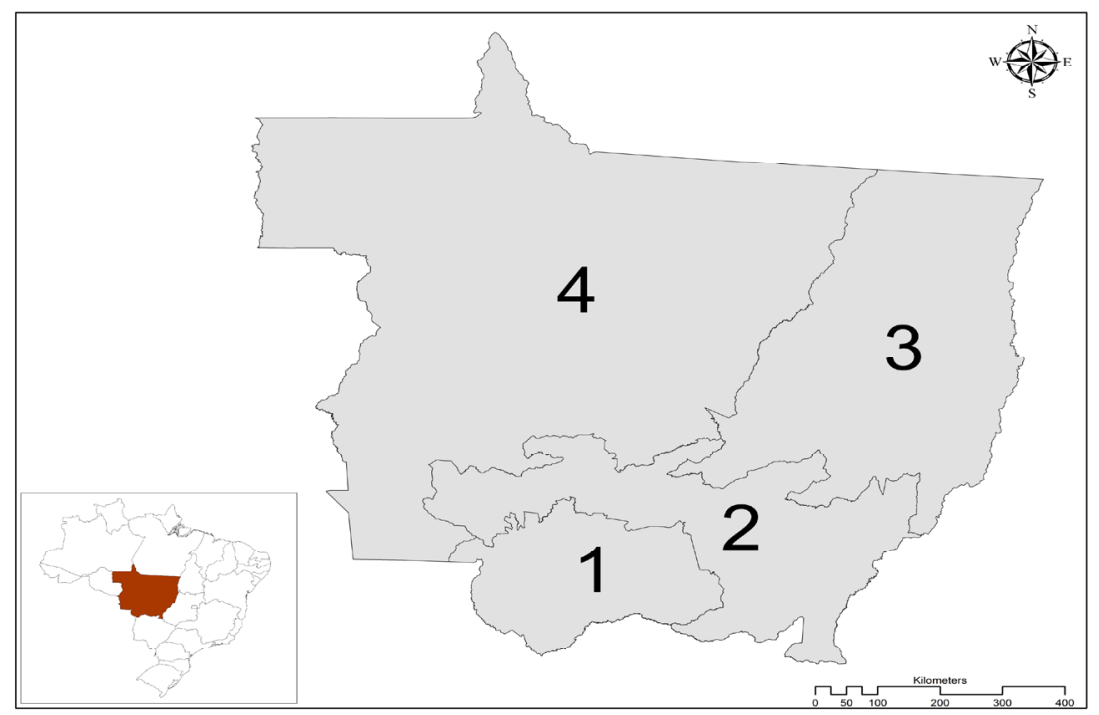

Table 1. Census and sample data in the state of Mato Grosso.

\begin{tabular}{lccccc}
\hline Region & $\begin{array}{c}\text { Number of } \\
\text { municpalities }\end{array}$ & $\begin{array}{c}\text { Properties with } \\
\text { reproductive } \\
\text { activity }\end{array}$ & $\begin{array}{c}\text { Sampled } \\
\text { properties }\end{array}$ & $\begin{array}{c}\text { Females aged } \\
\geq 24 \text { months }\end{array}$ & $\begin{array}{c}\text { Sampled females } \\
\text { aged } \geq 24 \text { months }\end{array}$ \\
\hline 1. Pantanal & 07 & 7778 & 344 & 1021623 & 3204 \\
2. Milk & 50 & 26924 & 296 & 2365639 & 2831 \\
3. Fattening & 27 & 18485 & 300 & 2533207 & 3193 \\
4. Breeding & 57 & 50930 & 313 & 5299557 & 3207 \\
\hline Total & 141 & 104117 & 1253 & 11220026 & 12435 \\
\hline
\end{tabular}

Table 2. Prevalence of herds and animals infected with bovine brucellosis in the state of Mato Grosso.

\begin{tabular}{lcccccc}
\hline \multirow{2}{*}{ Region } & \multicolumn{3}{c}{ Proprieties } & \multicolumn{3}{c}{ Females $\geq 24$ months } \\
\cline { 2 - 7 } & $\begin{array}{c}\text { Positive/ } \\
\text { sampled }\end{array}$ & $\begin{array}{c}\text { Prevalence } \\
(\%)\end{array}$ & CI95\% (\%) & $\begin{array}{c}\text { Positive/ } \\
\text { sampled }\end{array}$ & $\begin{array}{c}\text { Prevalence } \\
(\%)\end{array}$ & CI95\% (\%) \\
\hline 1. Pantanal & $73 / 344$ & 21.2 & $17.2-25.9$ & $98 / 3204$ & 6.4 & $3.1-12.8$ \\
2. Milk & $51 / 296$ & 17.2 & $13.3-22.0$ & $74 / 2831$ & 3.7 & $2.1-6.5$ \\
3. Fattening & $102 / 300$ & 34.0 & $28.8-39.6$ & $163 / 3193$ & 7.2 & $3.2-15.2$ \\
4. Breeding & $76 / 313$ & 24.3 & $19.8-29.4$ & $129 / 3207$ & 4.4 & $2.6-7.3$ \\
\hline Total & $302 / 1253$ & 24.0 & $21.3-26.8$ & $464 / 12435$ & 5.1 & $3.5-7.2$ \\
\hline
\end{tabular}


Table 3. Prevalence of herds infected with bovine brucellosis, stratified by type of farming in the regions in the state of Mato Grosso.

\begin{tabular}{lcccccc}
\hline \multirow{2}{*}{ Region } & \multicolumn{2}{c}{ Beef } & \multicolumn{2}{c}{ Dairy } & \multicolumn{2}{c}{ Mixed } \\
\cline { 2 - 6 } & $\begin{array}{c}\text { Prevalence } \% \\
\left(\mathrm{p} / \mathrm{e}^{*}\right)^{1}\end{array}$ & CI 95\% (\%) & $\begin{array}{c}\text { Prevalence \% } \\
(\mathrm{p} / \mathrm{e})\end{array}$ & CI 95\% $(\%)$ & $\begin{array}{c}\text { Prevalence \% } \\
(\mathrm{p} / \mathrm{e})\end{array}$ & CI 95\% (\%) \\
\hline 1. Pantanal & $24.6(46 / 187)$ & $18.8-31.1$ & $7.8(6 / 77)$ & $3.2-15.5$ & $26.2(21 / 80)$ & $17.7-36.7$ \\
2. Milk & $24.5(35 / 143)$ & $18.0-32.0$ & $9.6(11 / 114)$ & $5.2-16.1$ & $12.8(5 / 39)$ & $4.8-26.2$ \\
3. Fattening & $41.7(83 / 199)$ & $35.0-48.7$ & $13.8(8 / 58)$ & $6.6-24.5$ & $25.6(11 / 43)$ & $14.2-40.1$ \\
4. Breeding & $30.5(64 / 210)$ & $24.5-37.0$ & $8.9(7 / 79)$ & $3.9-16.7$ & $20.8(5 / 24)$ & $8.1-40.3$ \\
\hline
\end{tabular}

* positive/ examined.

Table 4. Comparison of the prevalence rates (P) of infected herds and animals with bovine brucellosis between the present study (2014) and that carried out in 2002 in Mato Grosso.

\begin{tabular}{lcccccccc}
\hline \multirow{2}{*}{ Region } & \multicolumn{4}{c}{ properties } & \multicolumn{3}{c}{ animals } \\
\cline { 2 - 9 } & \multicolumn{3}{c}{2002} & \multicolumn{2}{c}{2014} & \multicolumn{2}{c}{2002} & 2014 \\
\cline { 2 - 9 } & $\mathrm{P}(\%)$ & CI 95\% (\%) & P (\%) & CI 95\% (\%) & P (\%) & CI 95\% (\%) & P (\%) & CI 95\% (\%) \\
\hline 1. Pantanal & 36.9 & $29.2-45.2$ & 21.2 & $17.2-25.9$ & 7.9 & $3.0-12.9$ & 6.4 & $3.1-12.8$ \\
2. Milk & 27.2 & $22.8-32.1$ & 17.2 & $13.3-22.0$ & 4.1 & $2.8-5.4$ & 3.7 & $2.1-6.5$ \\
3. Fattening & 40.4 & $38.8-46.2$ & 34.0 & $28.8-39.6$ & 8.1 & $5.2-11.1$ & 7.2 & $3.2-15.2$ \\
4. Breeding & 50.3 & $44.5-56.1$ & 24.3 & $19.8-29.4$ & 15.3 & $9.2-21.3$ & 4.4 & $2.6-7.3$ \\
\hline Total & 41.2 & $38.0-44.4$ & 24.0 & $21.3-26.8$ & 10.2 & $7.4-13.1$ & 5.1 & $3.5-7.2$ \\
\hline
\end{tabular}

Table 5. Results of univariate analysis of potential risk factors for bovine brucellosis $(\mathrm{p}<0.05)$ in the state of Mato Grosso.

\begin{tabular}{|c|c|c|c|c|}
\hline Variable & Total no. of properties & $\begin{array}{l}\text { Number of properties with } \\
\text { infected herds }\end{array}$ & $\%$ & $\mathrm{P}$ value \\
\hline $\begin{array}{l}\text { Number of female } \\
\text { animals aged } \geq 24 \\
\text { months }\end{array}$ & & & & $<0.0001$ \\
\hline$\leq 85^{*}$ & 945 & 179 & 18.9 & \\
\hline$\geq 86$ & 308 & 123 & 39.9 & \\
\hline Type of usage & & & & $<0.0001$ \\
\hline Beef & 739 & 228 & 30.9 & \\
\hline Dairy & 328 & 32 & 9.8 & \\
\hline Mixed & 186 & 42 & 22.6 & \\
\hline $\begin{array}{l}\text { Introduction of } \\
\text { reproductive animals }\end{array}$ & & & & 0.006 \\
\hline No & 601 & 124 & 20.6 & \\
\hline Yes & 652 & 178 & 27.3 & \\
\hline Picket farrowing & & & & 0.002 \\
\hline No & 837 & 180 & 21.5 & \\
\hline Yes & 416 & 122 & 29.3 & \\
\hline Sharing of grazing & & & & 0.037 \\
\hline No & 1056 & 243 & 23.0 & \\
\hline Yes & 197 & 59 & 29.3 & \\
\hline
\end{tabular}


continuation

\begin{tabular}{lcccc}
\hline $\begin{array}{l}\text { Introduction of new } \\
\text { cattle }\end{array}$ & & & 0.05 \\
$\quad$ No & 838 & 188 & 22.4 & \\
$\quad$ Yes & 415 & 114 & 27.5 & 0.004 \\
\hline $\begin{array}{l}\text { Presence of wild } \\
\text { animals }\end{array}$ & & & \\
$\quad$ No & 479 & 94 & 19.6 & \\
$\quad$ Yes & 774 & 208 & 26.9 & 0.001 \\
\hline Presence of horses & & & & \\
$\quad$ No & 240 & 38 & 26.1 & 0.033 \\
$\quad$ Yes & 1013 & 264 & & \\
\hline Presence of sheep & & & \\
$\quad$ and goats & 1083 & 250 & 23.1 & \\
$\quad$ No & 170 & 52 & 30.6 & \\
$\quad$ Yes & & & \\
\hline
\end{tabular}

$* 3^{\text {rd }}$ quarter.

Table 6. Final model of multivariate logistic regression for risk factors for bovine brucellosis in the state of Mato Grosso.

\begin{tabular}{lcc}
\hline \multicolumn{1}{c}{ Variable } & OR & CI 95\% \\
\hline $\begin{array}{l}\text { Number of female animals aged } \geq 24 \text { months } \\
\leq 85^{*}\end{array}$ & \\
$\quad 2.15$ & $1.6-2.9$ \\
\hline Type of use & & \\
$\quad$ Dairy & 2.95 & $1.2-3.5$ \\
$\quad$ Mixed & 3.26 & $2.7-4.9$ \\
$\quad$ Beef & & \\
\hline Sharing of pasture & 1.56 & $1.1-2.2$ \\
$\quad$ No & & \\
$\quad$ Yes & 1.32 & $1.002-1.7$ \\
\hline Introduction of reproductive animals & & \\
$\quad$ No & & \\
$\quad$ Yes & & \\
$* 3^{\text {rd }}$ quarter. &
\end{tabular}

\section{Discussion}

The results in Table 2 show that the prevalence of infected herds remains high throughout the state, but with a significant decrease compared to the 2002 study by Negreiros et al. (2009) (Table 4). The decrease in the prevalence of infected herds due to vaccination was also found in Mato Grosso do Sul, Minas Gerais, and Rondônia (DIAS et al., 2016; ANZAI et al., 2016; INLAMEA et al., 2016; LEAL FILHO et al., 2016; OLIVEIRA et al., 2016; SILVA et al., 2016).
In Mato Grosso State, there was a remarkable decrease in the prevalence of infected herds in all evaluated regions, except in the Fattening region (3), where the results were at the limit of statistical significance (Table 4). The greatest decrease was observed in the Breeding region (4). Since the rates of vaccination of calves with B19 were homogeneous for all regions, this decrease is likely due to development of a higher-quality vaccination process, from the purchase of the vaccine to its application. 
Table 3 shows a trend of higher prevalence of infected herds in beef, and lower in dairy farms, which corroborates the results obtained in 2002 by Negreiros et al. (2009). It should be noted that, compared to 2002, the prevalence of infected herds in dairy properties decreased significantly in all regions except the Fattening region (3).

Compared to the 2002 study, there was a significant decrease in the prevalence of animals in the state as well as the Breeding region (4) (Tables 2 and 4), following what has already been outlined in the previous paragraph. In other regions, there was a decrease in the point value of prevalence in animals, but without statistical differences.

Therefore, the state should continue its vaccination program with emphasis on the quality of the process, from the purchase of the vaccine to its application. Furthermore, it should also encourage the use of non-antibody inducing vaccines in adult animals, since this practice helps to lower prevalence rates (SOUZA et al., 2016). In Pantanal, since there was little compliance from the producer with the use of non-antibody inducing vaccines to replace B19, as prescribed by state law, the state must develop further strategies to encourage this practice.

The final model of logistical regression showed that the introduction of breeding, herd size, pasture sharing, and farms used for mixed and beef purposes are associated with $B$. abortus infected herds (Table $6)$.

As reported in international literature, the introduction of breeding animals is the classic risk factor for bovine brucellosis (KELLAR et al., 1976; NICOLETTI, 1980; CRAWFORD et al., 1990). In Brazil, this variable was also seen as a risk factor for bovine brucellosis in the states of Bahia, Goias, Minas Gerais, Paraná, São Paulo, and Mato Grosso do Sul (ALVES et al., 2009; ROCHA et al., 2009; GONÇALVES et al., 2009; DIAS et al., 2009a, 2009b; KLEIN-GUNNEWIEK et al., 2009; LEAL FILHO, 2016). The introduction or replacement of breeding is routinely conducted without prior testing of animals or knowledge of the health conditions of their herd of origin.

Numerous international authors (KELLAR et al., 1976; NICOLETTI, 1980; SALMAN; MEYER, 1984) have reported an association between herd size and brucellosis. In Brazil, this association was also found in the states of Rondônia, Rio de Janeiro, Sergipe, Tocantins, São Paulo, Mato Grosso do Sul, and Mato Grosso in 2002 (AGUIAR et al., 2007; KLEIN-GUNNEWIEK et al., 2009; SILVA et al., 2009; OGATA et al., 2009; DIAS et al., 2009b; CHATE et al., 2009; NEGREIROS et al., 2009). The dynamics of brucellosis and some characteristics of the largest herds, such as the greater need to replace animals and difficulty in implementing disease control measures, facilitate the transmission of brucellosis (CRAWFORD et al., 1990). Christie (1969) observed that increasing the size of the herd results in increased probability of occurrence, persistence of infection, and difficulty in eradicating brucellosis. Therefore, the larger the herd, the greater the risk of introducing brucellosis and likelihood of its intra-herd spread.

Mixed and especially beef properties have presented higher risks of containing herds infected with brucellosis when compared to dairy properties. This is most likely attributed to their large herd size. In the state, the median number of cows in beef properties was 50,35 in mixed, and 19.5 in dairy.

The sharing of grazing land allows animals from different properties to coexist in the same environment and increases the likelihood of contact between those infected and those susceptible. Since the health conditions of the properties from which those animals originate can be distinct, this is an indirect form of contact between properties. Pasture rental, another indirect form of contact between properties, has been reported as a risk factor for bovine brucellosis in the states of Paraná and Rio de Janeiro (DIAS et al., 2009a; KLEIN-GUNNEWIEK et al., 2009). The practice of pasture rental may favor the contact of animals with previously contaminated 
environments. According to Wray (1975), the main risk of infection with $B$. abortus is related to environmental contamination by abortion products. Depending on the environmental conditions, abortion products can maintain the viability of the B. abortus for up to 180 days (CRAWFORD et al., 1990).

\section{Conclusions}

There has been a reduction in the prevalence of infected herds since 2002; however, a high prevalence of infected herds and animals throughout the state still exists. Additionally, the use of non-inducing antibodies vaccine should be encouraged, especially in the Pantanal region where the management of the animals is complicated by the flood and ebb cycle. Furthermore, the state should make greater efforts towards prevention of shared grazing between herds with unknown health conditions and education of the producers on methods of assessing the breeding animals for brucellosis before introducing them into their properties.

\section{Acknowledgements}

We would like to acknowledge the following: MAPA, the INDEA veterinarians for conducting the fieldwork; Ana Carolina Schmidt and Alison Cericatto for their valuable collaboration; the LASA-MT and LANAGRO-MG for carrying out the serological tests; the National Council for Scientific and Technological Development (CNPq) for the D.M. Aguiar productivity grant; Fapesp for financial support.

\section{References}

AGUIAR, D. M.; CAVALCANTE, G. T.; LABRUNA, M. B.; VASCONCELLOS, S. A.; RODRIGUES, A. A. R.; MORAIS, Z. M.; CAMARGO, L. M. A.; GENNARI, S. M. Risk factors and seroprevalence of Brucella spp. in cattle from western Amazon, Brazil. Arquivos do Instituto Biológico, São Paulo, v. 74, n. 4, p. 301-305, 2007.
ALMEIDA, E. C.; FREITAS, A. A.; PONTUAL, K. A. Q.; SOUZA, M. M. A.; AMAKU, M.; DIAS, R. A.; FERREIRA, F.; TELLES, E. O.; HEINEMANN, M. B.; GONÇALVES, V. S. P.; EVÊNCIO NETO, J.; MARVULO, M. F. V.; GRISI-FILHO, J. H. H.; FERREIRA NETO, J. S.; SILVA, J. C. R. Prevalence and associated risk factors for bovine brucellosis in the state of Pernambuco, Brazil. Semina: Ciências Agrárias, Londrina, v. 37, n. 5, p. 3413-3424, 2016. Suplemento 2.

ALVES, A. J. S.; GONÇALVES, V. P. S.; FIGUEIREDO, V. C. F.; LOBO, J. R.; BAHIENSE, L.; AMAKU, M.; FERNANDO, F.; FERREIRA NETO, J. S.; DIAS, R. A. Situação epidemiológica da brucelose bovina no Estado da Bahia. Arquivo Brasileiro de Medicina Veterinária e Zootecnia, Belo Horizonte, v. 61, p. 6-13, 2009. Suplemento 1.

AMAKU, M.; DIAS, R. A.; FERREIRA NETO, J. S.; FERREIRA, F. Modelagem matemática do controle da brucelose bovina por vacinação. Arquivo Brasileiro de Medicina Veterinária e Zootecnia, Belo Horizonte, v. 61, p. 135-141, 2009. Suplemento 1.

ANZAI, E. K.; COSTA, D.; SAID, A. L. P. R.; GRISI-FILHO, J. H. H.; AMAKU, M.; DIAS, R. A.; FERREIRA, F.; GALVIS, J. O. A.; GONÇALVES, V. S. P.; HEINEMANN, M. B.; TELLES, E. O.; FERREIRA NETO, J. S. An update on the epidemiological situation of bovine brucellosis in the state of Espírito Santo, Brazil. Semina: Ciências Agrárias, Londrina, v. 37, n. 5, p. 3437-3448, 2016. Suplemento 2.

ASSOCIAÇÃO DOS CRIADORES DE MATO GROSSO - ACRIMAT. Informativo Mensal da Associação dos Criadores de Mato Grosso. 52 $2^{\text {th }}$ ed. Cuiabá: Acrimat, jan. 2015. Ano 7.

AZEVEDO, S. S.; FERREIRA NETO, J. S.; DIAS, R. A.; FERREIRA, F.; AMAKU, M.; FIGUEIREDO, V. C. F.; LOBO, J. R.; GONÇALVES, V. S. P.; SOUZA, A. C.; VASCONCELLOS, S. A. Situação epidemiológica da brucelose bovina no Estado do Espírito Santo. Arquivo Brasileiro de Medicina Veterinária e Zootecnia, Belo Horizonte, v. 61, p. 19-26, 2009. Suplemento 1.

BAUMGARTEN, K. D.; VELOSO, F. P.; GRISI-FILHO, J. H. H.; FERREIRA, F.; AMAKU, M.; DIAS, R. A.; TELLES, E. O.; HEINEMANN, M. B.; GONÇALVES, V. S. P.; FERREIRA NETO, J. S. Prevalence and risk factors for bovine brucellosis in Santa Catarina State, Brazil. Semina: Ciências Agrárias, Londrina, v. 37, n. 5, p. 3425-3436, 2016. Suplemento 2.

BORBA, M. R.; STEVENSON, M. A.; GONÇALVES, V. S. P.; FERREIRANETO, J. S.; FERREIRA, F.; AMAKU, M.; TELLES, E. O.; SANTANA, S. S.; FERREIRA, J. C. A.; LÔBO, J. R.; FIGUEIREDO, V. C. F.; DIAS, R. 
A. Prevalence and risk-mapping of bovine brucellosis in Maranhão State, Brazil. Preventive Veterinary Medicine, v. 110, n. 2, p. 169-176, 2013.

CHATE, S. C.; DIAS, R. A.; AMAKU, M.; FERREIRA, F.; MORAES, G. M.; COSTA NETO, A. A.; MONTEIRO, L. A. R. C.; LOBO, J. R.; FIGUEIREDO, V. C. F.; GONÇALVES, V. S. P.; FERREIRA NETO, J. S. Situação epidemiológica da brucelose bovina no Estado do Mato Grosso do Sul. Arquivo Brasileiro de Medicina Veterinária e Zootecnia, Belo Horizonte, v. 61, p. 46-55, 2009. Suplemento 1.

CHRISTIE, T. E. Eradication of brucellosis in Northern Ireland: field problems and experiences. Veterinary Record, v. 85, p. 268-269, 1969.

CLEMENTINO, I. J.; DIAS, R. A.; AMAKU, M.; FERREIRA, F.; TELLES, E. O.; HEINEMANN, M. B.; GONÇALVES, V. S. P.; GRISI-FILHO, J. H. H.; FERREIRA NETO, J. S.; ALVES, C. J.; SANTOS, C. S. A. B.; AZEVEDO, S. S. Epidemiological situation of bovine brucellosis in the state of Paraiba, Brazil. Semina: Ciências Agrárias, Londrina, v. 37, n. 5, p. 3403-3412, 2016. Suplemento 2.

CRAWFORD, R. P.; HUBER, J. D.; ADAMS, B. S. Epidemiology and surveillance. In: NIELSEN, K.; DUNCAN, J. R. (Ed.). Animal brucellosis. Boca Raton: CRC Press, 1990. p. 131-151.

DEAN，A. G.; DEAN，J. A; COULOMBIER，D.; BRENDEL, K. A.; SMITH, D. C.; BURTON, A. H.; DICKER, R. C.; SULLIVAN, K.; FAGAN, R. F.; ARNER, T. G. Epi Info 6.: a word processing database, and statistics program for epidemiology on microcomputers. Atlanta: Center for Diseases Control and Prevention, 1994. $601 \mathrm{p}$.

DIAS, J. A.; MÜLLER, E. E.; DIAS, R. A.; FREITAS, J. C.; AMAKU, M.; FERREIRA, F.; SILVA, M. C. P.; LOBO, J. R.; FIGUEIREDO, V. C. F.; GONÇALVES, V. S. P.; FERREIRA, NETO, J. S. Situação epidemiológica da brucelose bovina no Estado do Paraná. Arquivo Brasileiro de Medicina Veterinária e Zootecnia, Belo Horizonte, v. 61, p. 66-76, 2009a. Suplemento 1.

DIAS, R. A.; BELCHIOR, A. P. C.; FERREIRA, R. S.; GONÇALVES, R. C.; AGUIAR, R. S. C. B.; SOUSA, P. R.; SANTOS, A. M. A.; AMAKU, M.; FERREIRA, F.; TELLES, E. O.; GRISI-FILHO, J. H. H.; HEINEMANN, M. B.; GONÇALVES, V. S. P.; FERREIRA NETO, J. S. Controlling bovine brucellosis in the State of São Paulo, Brazil: results of ten years of vaccination program. Semina: Ciências Agrárias, Londrina, v. 37, n. 5, p. 3505-3518, 2016. Suplemento 2.
DIAS, R. A.; GONÇALVES, V. S. P.; FIGUEIREDO, V. C. F.; LOBO, J. R.; LIMA, Z. M. B.; PAULIN, L. M. S.; GUNNEWIEK, M. F. K.; AMAKU, M.; FERREIRA NETO, J. S.; FERREIRA, F. Situação epidemiológica da brucelose bovina no Estado de São Paulo. Arquivo Brasileiro de Medicina Veterinária e Zootecnia, Belo Horizonte, v. 61, p. 118-125, 2009b. Suplemento 1.

DOHOO, I.; MARTIN, W.; STRYHN, H. Methods in epidemiologic research. Charlottetown: University of Prince Edward Island, 2003.

FARIA, J. F. Situação da brucelose no Brasil. Comumunicações Científicas da Faculdade de Medicina Veterinária e. Zootecnia, São Paulo, v. 8, n. 2, p. 161175, 1984.

FLETCHER, R. H.; FLETCHER, S. W.; WAGNER, E. H. Clinical epidemiology: the essentials. $2^{\text {th }}$ ed. Baltimore: Williams \& Wilkins, 1998. 246 p.

GONÇALVES, V. S. P.; DELPHINO, M. K. V. C.; DIAS, R. A.; FERREIRA, F.; AMAKU, M.; FERREIRA NETO, J. S.; PORTO, T. B.; ALVES, C. M.; FIGUEIREDO, V. C. F.; LÔBO, J. R. Situação epidemiológica da brucelose bovina no Estado de Minas Gerais. Arquivo Brasileiro de Medicina Veterinária e Zootecnia, Belo Horizonte, v. 61, p 35-45, 2009a. Suplemento 1.

GONÇALVES, V. S. P.; RIBEIRO, L. A.; CALDAS, R. A.; FRANCISCO, P. F. C.; DIAS, R. A.; FERREIRA, F.; AMAKU, M.; FERREIRA NETO, J. S.; FIGUEIREDO, V. C. F.; LÔBO, J. R.; BORGES, J. R. J. Situação epidemiológica da brucelose bovina no Distrito Federal. Arquivo Brasileiro de Medicina Veterinária e Zootecnia, Belo Horizonte, v. 61, p. 14-18, 2009b. Suplemento 1.

HOSMER, D. W.; LAMESHOW, S. Applied logistic regression. New York: John Wiley and Sons, 1989. 307 p.

INDEA/MT. Portaria conjunta SEDRAF/INDEA n. 02. Programa Estadual de Controle e Erradicação da Brucelose e Tuberculose Animal. Diário Oficial [do] Estado de Mato Grosso. Cuiabá: Secretaria de Desenvolvimento Rural e Agricultura Familiar, 2013.

INLAMEA, O. F.; ROCHA, A. B.; FERREIRA, F.; GRISI-FILHO, J. H. H.; HEINEMANN, M. B.; DIAS, R. A.; TELLES, E. O.; GONÇALVES, V. S. P.; AMAKU, M.; FERREIRA NETO, J. S. Effect of vaccination in lowering bovine brucellosis in the state of Rondônia, Brazil. Semina: Ciências Agrárias, Londrina, v. 37, n. 5, p. 3493-3506, 2016. Suplemento 2.

KELLAR, J.; MARRA, R.; MARTIN, W. Brucellosis in Ontario: a case control study. Canadian Journal of Comparative Medicine, v. 40, n. 2, p. 119-128, 1976. 
KLEIN-GUNNEWIEK, M. F. C.; AMAKU, M.; DIAS, R. A.; FERREIRA, F.; GITTI, C. B.; PEREIRA, L. A; FIGUEIREDO, V. C. F.; LOBO, J. R.; GONÇALVES, V. S. P.; FERREIRA NETO, J. S. Situação epidemiológica da brucelose bovina no Estado do Rio de Janeiro. Arquivo Brasileiro de Medicina Veterinária e Zootecnia, Belo Horizonte, v. 61, p. 77-84, 2009. Suplemento 1.

LAGE, A. P.; ROXO, E.; MÜLlER, E.; POESTER, F.; CAVALLÉRO, J. C. M.; FERREIRA NETO, J. S.; MOTA, P. M. P. C.; GONÇALVES, V. S. P. Programa nacional de controle e erradicação da brucelose e da tuberculose animal (PNCEBT). Brasília: Ministério da Agricultura, Pecuária e Abastecimento, 2006. 184 p. (Manual Técnico). Disponível em: <http://www. agricultura.gov.br>. Acesso em: 5 ago. 2015.

LEAL FILHO, J. M.; BOTTENE, I. F. N.; MONTEIRO, L. A. R. C.; PELlEGRIN, A. O.; GONÇALVES, V. S. P.; FERREIRA, F.; DIAS, R. A.; AMAKU, M.; TELLES, E. O.; GRISI-FILHO, J. H. H.; HEINEMANN, M. B.; FERREIRA NETO, J. S Control of bovine brucellosis from 1998 to 2009 in the state of Mato Grosso do Sul, Brazil. Semina: Ciências Agrárias, Londrina, v. 37, n. 5, p. 3467-3478, 2016. Suplemento 2 .

MARVULO, M. F. V.; FERREIRA, F.; DIAS, R. A.; AMAKU, M.; GROFF, A. C. M.; GONÇALVES, V. S. P.; FIGUEIREDO, V. C. F.; LOBO, J. R.; FERREIRA NETO, J. S. Situação epidemiológica da brucelose bovina no Estado do Rio Grande do Sul. Arquivo Brasileiro de Medicina Veterinária e Zootecnia, Belo Horizonte, v. 61, p. 93-102, 2009. Suplemento 1.

NEGREIROS, R. L.; DIAS, R. A.; FERREIRA, F.; FERREIRA NETO, J. S.; GONÇALVES, V. S. P.; SILVA, M. C. P.; FIGUEIREDO, V. C. F.; LÔBO, J. R.; FREITAS, J.; AMAKU, M. Situação epidemiológica da brucelose bovina no Estado do Mato Grosso. Arquivo Brasileiro de Medicina Veterinária e Zootecnia, Belo Horizonte, v. 61, p. 56-65, 2009. Suplemento 1.

NICOLETTI, P. The epidemiology of bovine brucellosis. Advances in Veterinary Science and Comparative Medicine, v. 24, p. 69-98, 1980.

OGATA, R. A.; GONÇALVES, V. S. P.; FIGUEIREDO, V. C. F.; LOBO, J. R.; RODRIGUES, A. L.; AMAKU, M.; FERREIRA, F.; FERREIRA NETO, J. S.; DIAS, R. A. Situação epidemiológica da brucelose bovina no Estado do Tocantins. Arquivo Brasileiro de Medicina Veterinária e Zootecnia, Belo Horizonte, v. 61, p. 126134, 2009. Suplemento 1.

OLIVEIRA, L. F.; DORNELES, E. M. S.; MOTA, A. L. A. A.; GONÇALVES, V. S. P.; FERREIRA NETO, J. S.; FERREIRA, F.; DIAS, R. A.; TELLES, E. O.; GRISIFILHO, J. H. H.; HEINEMANN, M. B.; AMAKU, M.;
LAGE, A. P. Seroprevalence and risk factors for bovine brucellosis in the State of Minas Gerais, Brazil. Semina: Ciências Agrárias, Londrina, v. 37, n. 5, p. 3449-3446, 2016. Suplemento 2.

PAULIN, L. M.; FERREIRA NETO, J. S. A Experiência brasileira no combate à brucelose bovina. Arquivos do Instituto Biológico, São Paulo, v. 69, n. 2, p. 105-112, 2002.

O combate à brucelose bovina: situação brasileira. Jaboticabal: Fundação de Estudos e Pesquisas em Agronomia, Medicina Veterinária e Zootecnia, 2003. $154 \mathrm{p}$.

POESTER, F.; FIGUEIREDO, V. C. F.; LÔBO, J. R.; GONÇALVES, V. S. P.; LAGE, A. P.; ROXO, E.; MOTA, P. M. P. C.; MÜLLER, E. E.; FERREIRA NETO, J. S. Estudos de prevalência da brucelose bovina no âmbito do programa nacional de controle e erradicação de brucelose e tuberculose: introdução. Arquivo Brasileiro de Medicina Veterinária e Zootecnia, Belo Horizonte, v. 61, p. 1-5, 2009. Suplemento 1.

ROCHA, W. V.; GONÇALVES, V. S. P.; COELHO, C. G. N. F. L.; BRITO, W. M. E. D.; DIAS, R. A.; DELPHINO, M. K. V. C.; FERREIRA, F.; AMAKU, M.; FERREIRA NETO, J. S.; FIGUEIREDO, V. C. F.; LÔBO, J. R.; BRITO, L. A. B. Situação epidemiológica da brucelose bovina no Estado de Goiás. Arquivo Brasileiro de Medicina Veterinária e Zootecnia, Belo Horizonte, v. 61, p. 27-34, 2009. Suplemento 1.

SALMAN, M. D.; MEYER, M. E. Epidemiology of bovine brucellosis in the Mexicali Valley, Mexico: literature review of disease-associated factors. American Journal of Veterinary Research, Chicago, v. 45, p. $1557-$ 1560, 1984.

SANTOS, R. L.; MARTINS, T. M.; BORGES, A. M.; PAIXÃO, T. A. Economic losses due to bovine brucellosis in Brazil. Pesquisa Veterinária Brasileira, Rio de Janeiro, v. 33, n. 6, p. 759-764, 2013.

SIKUSAWA, S.; AMAKU, M.; DIAS, R. A.; FERREIRA NETO, J. S.; MARTINS, C.; GONÇALVES, V. S. P.; FIGUEIREDO, V. C. F.; LOBO, J. R.; FERREIRA, F. Situação epidemiológica da brucelose bovina no Estado de Santa Catarina. Arquivo Brasileiro de Medicina Veterinária e Zootecnia, Belo Horizonte, v. 61, p. $103-$ 108, 2009. Suplemento 1.

SILVA, N. S.; GROFF, A. C. M.; VIDOR, A. C. M.; GRISI-FILHO, J. H. H.; HEINEMANN, M. B.; DIAS, R. A.; TELlES, E. O.; GONÇALVES, V. S. P.; AMAKU, M.; FERREIRA, F.; FERREIRA NETO, J. S. Epidemiological situation of brucellosis after implementation of the vaccination program in Rio 
Grande do Sul State, Brazil. Semina: Ciências Agrárias, Londrina, v. 37, n. 5, p. 3519-3530, 2016. Suplemento 2.

SILVA, V. G. S.O.; DIAS, R.A.; FERREIRA, F.;AMAKU, M.; COSTA, E. L. S.; LOBO, J. R.; FIGUEIREDO, V. C. F.; GONÇALVES, V. S. P.; FERREIRA NETO, J. S. Situação epidemiológica da brucelose bovina no Estado de Sergipe. Arquivo Brasileiro de Medicina Veterinária e Zootecnia, Belo Horizonte, v. 61, p. 109-117, 2009. Suplemento 1.

SOUZA, V. A. F.; FERREIRA NETO, J. S.; AMAKU, M.; DIAS, R. A.; TELLES, E. O.; GRISI-FILHO, J. H. H.; HEINEMANN, M. B.; FERREIRA, F. Mathematical modeling of bovine brucellosis control using the RB51 vaccine. Semina: Ciências Agrárias, Londrina, v. 37, n. 5, p. 3767-3776, 2016. Suplemento 2.
THRUSFIELD, M. Veterinary epidemiology. $3^{\text {th }}$ ed. Oxford: Blackwell Science, 2007. 610 p.

VILLAR, K. S.; AMAKU, M.; DIAS, R. A.; FERREIRA NETO, J. S.; BENITEZ, F.; GONÇALVES, V. S. P.; FIGUEIREDO, V. C. F.; LOBO, J. R.; FERREIRA, F. Situação epidemiológica da brucelose bovina no Estado de Rondônia. Arquivo Brasileiro de Medicina Veterinária e Zootecnia, Belo Horizonte, v. 61, p. 85-92, 2009. Suplemento 1.

WRAY, C. Survival and spread of pathogenic bacteria of veterinary importance within the environment. Veterinary Bulletin, v. 8, p. 543-550, 1975. 
